\title{
Research on Business Opportunities of International Investment Banks in China
}

\author{
WANG BOGE ${ }^{1}$ \\ ${ }^{1}$ School of finance, Yunnan University of Finance and Economics, Kunming, China
}

\begin{abstract}
As China's capital market deepens reforms, international investment banks are also seeking further opportunities for business development in China. This article first introduces the corresponding overview of China's investment banking business and international investment banks, and analyzes the development of China's investment banking market from the four markets of IPO, equity refinancing, M\&A and restructuring and debt financing, and then from business contract, undertaking and sales, it analyzes the advantages and disadvantages of international investment banks. It is concluded that under the background of the continuous expansion of the China's investment banking business market, there are certain opportunities and development prospects for the development of international investment banks in China, but their operations need to be further improved. Based on this, relevant suggestions are proposed for international investment banks to operate in China.
\end{abstract}

\section{INTRODUCTION}

\section{A. Overview of China's investment banking business}

China's investment banks started relatively late and their main bodies are major securities companies. Compared with the developed markets such as the United States, the investment banking business of China's securities firms is still in the early stages of development. In 2019, China's investment banking business revenue was 48.3 billion yuan, equivalent to the level of the United States around 1995. China's investment banking business mainly includes equity business and debt financing business. Equity business includes domestic and overseas IPOs, sponsoring and sales of listed company refinancing and financial advisory services of enterprise M\&A and restructuring, among which the sponsoring and sales services of refinancing specifically include private placement, issuance of convertible bonds, allotment and other related businesses. Debt financing business includes bond issuance and sales and sponsorship business of other debt financing products, specifically including issuance of corporate bonds, financial bonds, local government bonds, ABS, ABN, REITS and other related businesses. 2020 is a great year for China's registration system and marketization reform. The implementation of the registration system for ChiNext, Science and Technology Innovation Board and corporate bonds, as well as the implementation of supporting policies for refinancing and major asset restructuring have all promoted the income of traditional Chinese investment banks. In addition, investment banks have opened up new growth points in the business of placing brokerage commissions and follow investment income. In the context of the comprehensive and deepening reform of China's capital market, investment banking business will undergo further strategic transformation. In the past five years, China's equity financing only accounted for about $2 \%$ of GDP and debt financing accounted for $30 \%$ of GDP. The future development of direct financing will drive equity financing business growth. At the same time, under the implementation of the registration system, the investment banking business of securities companies faces higher requirements in terms of pricing, sales, and information disclosure. The high-level transformation of brokerage business models will drive the coordinated development of integrated businesses.

\section{B. Current status of international investment banks' global operations}

International investment banks mainly include nine major investment banks, including Goldman Sachs, Morgan Stanley, JP Morgan Chase, Citibank, Merrill Lynch, Credit Suisse, UBS, Deutsche Bank, and Barclays; some well-known large investment banks, such as HSBC and Nomura Securities; there are also some boutique investment banks, such as Centerview Partners, Evercore and Lazard. Large-scale international investment banks cover a complete range of businesses and diversify. They continue to promote the growth of new businesses on the basis of consolidating their core business. For example, Goldman Sachs continues to maintain its leading position as an M\&A advisor in the industry, and is engaged in investment banking, global market business. Income from the asset management business continued to grow, and net income in the consumer and wealth management business 
reached a new high; Morgan Stanley gradually formed a two-wheel drive model of institutional business + wealth management, and established investment management, institutional securities and wealth management the three large module covers individuals and large, medium and small institutional clients. Among them, equity sales, especially IPO business, is a global leader. The wealth management business established in recent years accounts for half of the company's overall revenue. Boutique investment banks continue to focus on the scope of their business areas. Centerview Partners only focuses on mergers and acquisitions consulting and restructuring. Although it is small, it has participated in many largescale and complex transactions, such as Disney's US\$52.4 billion acquisition of some assets of 21 World Fox, thereby increasing business income.

\section{Current status of China's operations of international investment banks}

Before 2018, China allowed foreign investors to set up joint venture securities companies in China, but still restricted foreign investors from gaining control of securities firms. In 2018, the China Securities Regulatory Commission announced the "Administrative Measures for Foreign Investment in Securities Companies", allowing foreign ownership to reach $51 \%$ and gradually opening up the business scope. By April 1, 2020, the China Securities Regulatory Commission will abolish the restrictions on the foreign equity ratio of securities companies. So far, international investment banks have completed holdings of joint venture securities companies and launched investment banking business. Goldman Sachs, Morgan Stanley, and Credit Suisse Co., Ltd. have achieved capital increase to Goldman Sachs Gao Hua Securities Co., Ltd. and Morgan Stanley Huaxin through capital increase by foreign shareholders. Securities Co., Ltd. and Credit Suisse Founder Securities Co., Ltd. holdings. JPMorgan Chase and Nomura Securities newly established JPMorgan Chase Securities (China) and Nomura Orient International Securities in 2019 and achieved holdings. HSBC Qianhai Securities, established in 2017, is a foreign-controlled securities firm controlled by HSBC under the CEPA agreement. After entering the Chinese market, international investment banks mainly developed high-end and complex business areas such as cross-border business, institutional transactions and derivatives, wealth management and investment management, and competed with local securities. Since China only allowed foreign companies to control joint venture securities companies after 2018, the operation of international investment banks in China is still in the preliminary stage of preparation and development.

\section{LITERATURE REVIEW}

\section{A. Overview of Investment Banking}

Investment banking business covers a wide range, mainly divided into derivative business, innovative business and traditional business. Securities trading is the original business of investment banking. Investment banks act as market makers in securities trading to facilitate securities trading. M\&A financing, equity financing, fund management, $\mathrm{PE} / \mathrm{VC}$, etc. are innovative businesses of investment banking. Derivative business mainly refers to financial derivatives that reduce monetary risk and realize value preservation and appreciation. Innovative businesses are innovative businesses such as mergers and acquisitions consulting, fund management and venture capital that have spawned as investment banking competition continues to intensify. The extended business is mainly to reduce the risk of basic financial products and realize the financial derivatives generated by maintaining and increasing the value of assets [1].

Securities sales refers to the public issuance of securities or bonds in the primary market. Securities sales business is the traditional business of investment banking and the main source of core profits. Securities trading only invests in banks where securities brokers and securities dealers in the secondary market work. Dealers are entrusted by investors to conduct securities transactions and earn trading commissions from them. Financial advisory and consulting services are investment banks relying on their own financial resources, talent reserves, capital market operation experience and knowledge to provide customers with business planning and consulting related to asset transactions, financing and fundraising activities, and profit from them [2]. Asset securitization generally refers to the structural design of investment banks, that is, the process of revitalizing assets with poor liquidity and stable operating cash flow and issuing securities assets to realize asset revitalization. The business of mergers and acquisitions is a business with high technical connotation, involving complex financial and legal risks. Investment banks rely on their information, financial management and financing capabilities to provide assistance to customers, act as corporate M\&A consultants and charge a certain service fee. The project financing business uses only investment banks as financing consultants, comprehensively using financing methods such as issuing bonds, stocks, mortgage loans, and lending to provide a package of financing services for specific customers. Venture capital refers to the business that investment banks make equity investments in emerging companies in the initial stage of venture capital, and provide them with funds, and when the company enters a period of stable development, the equity will be realized to obtain excess returns [3]. Fund management business is a business in which securities companies charge fees for participating in fund offering, operation and management. Asset management is a new investment banking business model that emerged as the times require under the promotion of traditional transaction models and new market demands [4].

\section{B. Theoretical basis of investment banking}

\section{1) Economics of Scope Theory}

Economies of scope were originally proposed by American economist David Teece when analyzing corporate diversification strategies. Economies of scope refer to the fact that some survival factors can be used not only for the production of one product, but also for the 
production of other products. By improving the use efficiency, the cost is reduced and the production factors are more fully utilized. The kind of cost reduction brought about by increasing the variety of services or expanding the scope of production is called the economy of scope [5] Commercial banks have a large number of customers' information, and can use this information to provide investment banking services to customers and improve information utilization. When commercial banks enter the financial market, they can also use their good reputation to gain customer trust and improve investment banking services [6].

\section{2) Viewpoint Theory of Financial Function}

The theory of financial function view holds that there is competition and substitution among financial markets, financial products, financial institutions, financial markets and financial institutions. With the gradual development of business trends towards mixed operations, the cost of direct financing has dropped significantly. Therefore, investors are more inclined to trade through the direct financing market. This change has caused the traditional business scale of commercial banks to shrink and banks must expand into investment banking. To expand business areas and increase profits [7].

\section{3) Theory of Institutional Change}

The theory of institutional change believes that more efficient new systems can be created through institutional changes, and income expectations are the factors leading to reforms. An incomplete market and increasing returns determine the direction of institutional change. In the context of globalization and financial marketization, investors and fundraisers can choose a variety of investment and financing channels such as the primary market and the secondary market, which has changed the investment and financing methods. Commercial bank investment banking business emerged as a new investment and financing channel, breaking the traditional business model and exploring a new income model for commercial banks [8].

\section{ANALYSis OF ChINA'S INVESTMENT BANKING BUSINESS MARKET}

\section{A. IPO market}

With the further reform of China's capital market, the capacity of China's IPO market has increased in recent years. Except for the decline in the amount of IPO financing and the number of IPOs in 2018, the remaining years have shown a gradual upward trend, especially in 2020. Although the first half of the year experienced the outbreak of black swan of the epidemic, the amount and number of A-share IPOs reached new highs. As of September 10, according to Wind database statistics, the IPO financing amount reached 139.2 billion yuan and the number of issuers reached 248, which has exceeded IPO financing scale throughout the year of 2019. Specifically, from the perspective of province distribution, Beijing, Jiangsu, Zhejiang, and Guangdong have become provinces with more than 30 IPOs. From the perspective of industry distribution, semiconductor and semiconductor production equipment, capital goods, pharmaceutical biotechnology and life sciences, transportation and the cost of material II became the five largest industries in the IPO market in the first half of the year. From the perspective of sector composition, the science and technology innovation board has the largest financing scale, accounting for $54 \%$ of the overall IPO scale, followed by the main board and the ChiNext, each accounting for $24 \%$ of the IPO market and $14 \%$, the rapid development of the Science and Technology Innovation Board has made its overall financing scale account for more than half of the overall IPO financing scale. From the perspective of institution of sales and sponsorship, CITIC, CSC, and CICC's IPO sales sponsorship accounted for $30 \%$ of the market share, reaching 3 billion yuan, and the number and amount of sales reached $25 \%$ and $43 \%$ of the overall share, reaching 132 companies and 249.2 billion yuan, the top securities dominate most of the IPO market. Overall, China's IPO market is rapidly expanding due to the economic market recovery and multiple market policies.

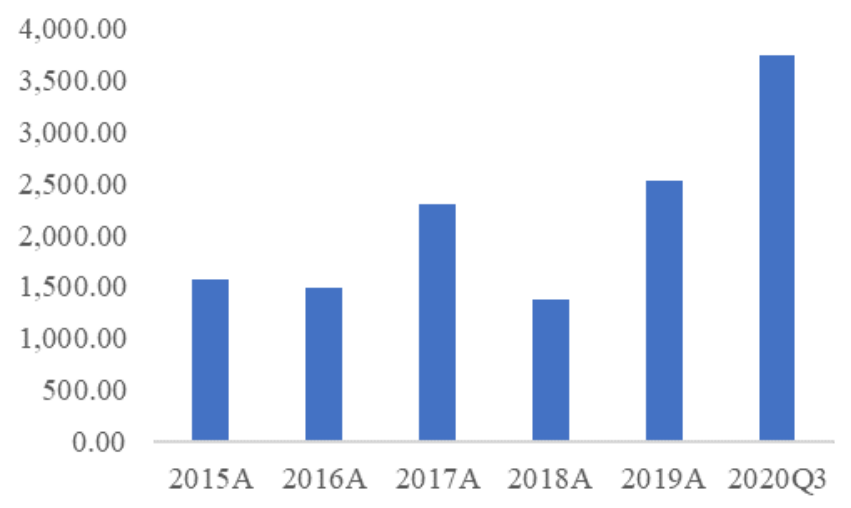

Figure 1: Amount of IPO financing over the years (100 million RMB yuan)

\section{B. Equity refinancing market}

The loosening of China's refinancing policy affects the pattern of the equity refinancing market. Specifically, although the amount of allotment financing has exceeded the financing scale of the previous year, the overall financing scale is relatively small. The financing amount and number are 41.7 billion yuan and 15 companies, and diversified finance accounts for $76 \%$ of the share of allotment financing. The financing industry is relatively single. The issuance of convertible bonds has been on the rise since 2011. In 2020, 145 convertible bonds have been issued and 155.7 billion yuan of funds have been raised. Although the number of convertible bonds in 2020 has exceeded 106 of last year, the funds raised was less than 247.7 billion yuan of last year. Among them, the number of convertible bonds issued by CITIC, CSC and Guotai Junan accounted for the top three market shares. The income from the issuance of convertible bonds accounted for $35 \%$ of the market share. The revenue is only 233 million yuan. The amount and number of additional issuances have been declining year by year since 2016, but after the policy revision for refinancing including private placement, the number of additional issuances reached 196 and 548 billion yuan in 2020, which is close 
to last year's 251companies and 688.7 billion yuan. Among them, the number of private placements and raised funds have exceeded the scale of the private placement in the previous three years. In terms of additional issuance, the income of CITIC, Huatai United Securities, and CSC accounted for $37 \%$ of the market, reaching 740 million yuan. Generally speaking, the policy encourages the development of the equity refinancing market. In the future, more and more companies will choose private placement financing based on the policy, and the scale of private placement financing will further increase.

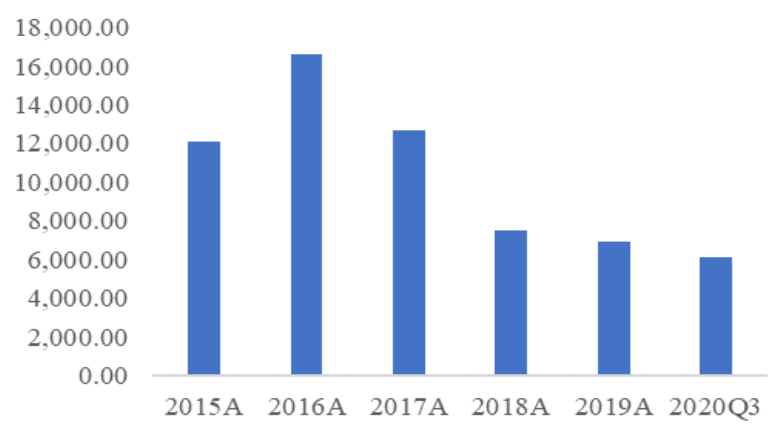

Figure 2: Amount of equity refinancing financing over the years (100 million RMB yuan)

\section{M\&A and Restructuring Market}

Since the first half of 2020 , the number and amount of M\&A transactions reached 3,818 orders and 644.4 billion yuan, a decrease of $22 \%$ and $46 \%$ year-on-year compared with the previous year. The decline was large. Specifically, in terms of industry distribution, the amount of industrial, real estate and information technology M\&A transactions accounted for the top three transactions in all industries, reaching 1,397, 69.5, and 57.6 billion yuan respectively. However, except for the real estate industry M\&A value which increased by $51 \%$ year-on-year, the rest fell by $41 \%$ and $28 \%$ year-on-year. From the perspective of method of mergers and acquisitions, the main method of mergers and acquisitions was agreement mergers with an amount of 369.2 billion yuan, followed by the increase of capital and the purchase of issued shares, which reached 110 billion yuan and 68.4 billion yuan, but both were down $30 \%, 22 \%$ and $79 \%$ compared with last year. In terms of institutional business, the Fed Securities, Minsheng Securities and CITIC have a transaction value of 81 billion yuan, accounting for $47 \%$ of the market share, and business concentration is relatively high. It can be seen that the overall size of the M\&A and restructuring market in the first half of the year has dropped significantly compared to the same period last year. However, based on the new regulations that the China Securities Regulatory Commission will relax its supervision on the supporting financing of listed companies' mergers and acquisitions, the amount and volume of mergers and acquisitions in the future will Further increase.

\section{Debt financing market}

At the beginning of 2020, China introduced a number of financial policies to support the stable operation of the bond market. In the first half of the year, China's bond market issued 24,018 issues of various types of bonds, an increase of $22 \%$ over the same period last year, with a total issuance amount of 26 trillion yuan, an increase of $19 \%$ over the same period last year, and the issuance scale achieved a rapid growth. The net financing amount of bonds in the whole market was 8.5 trillion yuan, up 54\% year-on-year, and the net financing scale increased significantly. Among them, short-term bonds in one year accounted for the main proportion, reaching $72 \%$ of the bond issuance in the same period; Interest rate bonds were issued for 1536 issues, with a year-on-year increase of $44 \%$, and the issuance scale showed a large increase. 440 issues of non-policy financial bonds were issued, up 58\% year-on-year, with a total issuance of 1,780 billion yuan, up 51\% year-on-year, and the scale of issuance increased significantly. Traditional credit bonds were issued for 6411 issues, with a year-on-year growth of $53 \%$. The issuance scale reached 6,450 billion yuan, with a year-onyear growth of $44 \%$. The issuance scale maintained a rapid growth. Total issuance of asset-backed securities reached 930 billion yuan, down 2.4\% year-on-year. Generally speaking, China's bond market developed rapidly in the first half of the year. Under the promotion of policies, the bond market is expected to further expand.

\section{ANALYSIS OF THE COMPETITIVE ADVANTAGES AND DISADVANTAGES OF INTERNATIONAL INVESTMENT BANKS}

\section{A. Business contract}

Business contract refers to the investment bank contracting projects through its own advantages. The amount of business contract determines the development of the investment bank. Different companies have different considerations when choosing securities companies, but compared with investment banks in China, international investment banks have certain disadvantages when contracting business in China. First, foreigncontrolled securities companies charge higher fees than domestic securities companies. Taking into account the cost factor, companies will prefer local securities companies. Secondly, local securities companies have closer ties with companies in China in terms of resource background and other aspects. The background of domestic shareholders also brings rich customer resources for local securities companies. Therefore, with the same level of professional ability and performance, the company will choose local securities that it is more familiar with to complete the corresponding business.

\section{B. Business undertaking}

Business undertakings include the entire process of due diligence, plan design, production of working papers and application materials, project declaration, and acceptance 
of inquiries from regulatory authorities. From 1991 to 2018, China's issuance management system has been an approval system. After 2018, the Sci-tech Innovation Board will implement a registration system in 2018. In 2020, the ChiNext will reform the registration system. The registration system essentially emphasizes the principle of information disclosure. Securities institutions submit application materials to the Shanghai Stock Exchange or the Shenzhen Stock Exchange, and submit them to the Securities Regulatory Commission for registration after approval. This shortens the review time of the previous approval system, but also requires investment banks to further improve their business capabilities such as investigation and review. Compared with foreign-controlled securities companies and local securities companies, foreign-controlled securities companies are more professional in net worth investigation and financial review, but local securities companies have long been conducting business in China and have a good understanding of various information, laws and regulations, regulatory policies, relevant industry dynamics and other investigation channels, and can quickly and accurately complete the investigation of information disclosure and other related work. On the whole, the International Investment Bank does not have obvious advantages in business undertaking.

\section{Business sales}

Business sales is the sales of issued securities, and pricing is the core of the business sales. From the perspective of pricing system, both the main board and the small and medium-sized board implement the approval system, so the price of issuing new shares cannot exceed 23 times the price-earnings ratio, while the science and technology board and ChiNext adopt the registration system, which adopts the inquiry pricing method, breaking the ceiling of 23 times earnings ratio, and establish the inquiry pricing mechanism with professional institutional investors as the main body. The leading saler negotiates with the issuer and finally sets the offering price according to the quoted price registered by the client. The reform of the registration system enables pricing to better reflect market demand and is conducive to the success of issuance, but it also places higher requirements on the business capabilities of investment banks. From this perspective, international investment banks have extensive experience in business sales under the registration system. Compared with local securities companies, they have more outstanding professional capabilities. Therefore, international investment banks have a strong advantage in business sales.

\section{CONCLUSIONS AND RECOMMENDATIONS}

\section{A. Research conclusions}

Generally speaking, under the background of the deepening reform of China's capital market, China's investment banking market has developed rapidly, and with the support of policies, it is expected to further expand in the future. Compared with domestic securities, international investment banks have their competitive advantages mainly in business sales. They have no obvious advantages in business undertaking, and even have certain disadvantages in business contract. Therefore, based on the current development of China's investment banking business market, international investment Banks have certain opportunities and potential for business development in China, but their operation needs to be further improved and enhanced.

\section{B. Suggestions based on the research conclusions of this article}

First, government should strengthen the construction of contracting channels, and employ professionals with work experience in local securities companies, especially those from top securities firms that have close connections with client resources, to contract projects for foreign-controlled securities companies, while reasonably controlling costs and increasing competitive advantages. Second, government should strengthen the localization of foreignfunded securities firms, and strengthen the construction of local talent team, improve the overall understanding and awareness of China's capital market, such as the dynamic understanding of business operation process, policy environment and review channels, thereby improving business undertaking capabilities. Finally, government should continue to give play to the advantages of sales of foreign securities firms. At the same time, foreign securities firms can expand their basic customer base by developing Internet models and merging and acquiring local small securities firms.

\section{REFERENCES}

1. Li Feng. Reengineering the investment-loan linkage culture and the transformation of commercial banks $[\mathrm{J}]$. Financial Forum, 2016, 21 (12): 6-14+39.

2. Wang Yiting, Cheng Suoao. Investment Banking Business of Commercial Banks of China: Theoretical Analysis, Model Comparison and Path Selection[J]. Southern Finance, 2017 (03): 18-27.

3. Pan Shi, Chen Xi. Current Status, Risks and Countermeasures of Investment Banking Business of Chinese Commercial Banks [J]. Journal of Henan Institute of Financial Management, 2008 (04): 63-66.

4. Zhao Juhui, $\mathrm{Xu}$ Jing. Huang Ying. Research on the Synergy Effect of China Commercial Bank's Investment Banking Business [J]. Journal of Liaoning Normal University (Natural Science Edition), 2016, 39 (01): 23-29.

5. Li Yali. FICC Business of American Investment Bank: Development Process, Strategy and Enlightenment [J]. Southern Finance, 2016 (9): 61-68.

6. Ma Hongxia, Sun Guohua. An analysis of the American investment bank crisis and its transformation. International Financial Research, 2009 (3): 43-51.

7. Li Yong, Chen Yaogang. Goldman Sachs Investment Banking Business: Experience and Reference [J]. Financial Forum, 2007 (3): $10-15$.

8. Huang Fubin. Discussion on the development countermeasures of investment banking business of commercial banks [J]. Modern Economic Information, 2012 (13): 196 